\title{
Refleksi Nilai-nilai Eksistensialisme pada Tokoh Nidah Kirani dalam Novel "Tuhan, Ijinkan Aku Menjadi Pelacur!" Karya Muhidin M. Dahlan
}

\author{
${ }^{1}$ Ahmad Yasid, ${ }^{2}$ Abd. Syakur \\ ${ }^{1}$ STKIP PGRI Sumenep, Indonesia \\ ${ }^{2}$ STKIP PGRI Sidoarjo, Indonesia
}

Email: ${ }^{1}$ ahmad.yasidsaja @ stikippgrisumenep.ac.id, ${ }^{2}$ syakurabdmpd@ gmail.com

\section{Tersedia Online di \\ http://www.jurnal.unublitar.ac.id/i ndex.php/briliant}

\begin{tabular}{l}
\hline Sejarah Artikel \\
\hline Diterima pada 18 April 2020 \\
Disetujui pada 1 Mei 2020 \\
Dipublikasikan pada 30 Mei 2020 \\
Hal. 252-263
\end{tabular}

\section{Kata Kunci:}

Eksistensialisme; ilmu filsafat;

Novel; Tuhan

\section{DOI:}

http://dx.doi.org/10.28926/briliant. v3i4.460

\begin{abstract}
Abstrak: Ilmu filsafat memiliki beberapa aliran, salahsatunya adalah eksistensialime menekankan pada diri manusia. Manusia dipandang suatu mahluk yang berinteraksi dan menelaah terhadap cara manusia ada di dunia dengan kesadarannya. Metode dalam mendapatkan data kongkit dan valid, maka dibutuhkan dokumentasi, sebab dalam penelitian ini bersifat kualitatif deskriptif yang kemudian menelaah dan mendeskripsikan relasi dan tujuan serta nilai yang terkandung dalam objek penelitian. Hasil penelitian yaitu kebebasan manusia, antara "kebebasan untuk" dan "Kebebasan diri", nilai-nilai eksistensialisme, absurditas kebebasan manusia, para eksistensialis percaya bahwa kebersamaan merupakan sebuah ciri yang sangat esensial dari keberadan manusia itu sendiri serta tidaklan semata-mata kebetulan saja melainkan suatu yang seharusnya ada.
\end{abstract}

\section{PENDAHULUAN}

Karya sastra merupakan suatu karya yang lahir dari perasaan dan imajinasi pengarang serta mempunyai peran penting dalam kehidupan nyata ini baik sebagai media pendidikan, kontrol sosial, pemberontakan, juga berfungsi sebagai penyampaian pesan kepada masyarakat atas segala polemik atau persoalan yang ada sehingga kita dapat mempunyai gambaran atas apa yang harus kita lakukan disaat harus menghadapi persoalan yang sama dengan apa yang terjadi dalam sebuah karya sastra. Oleh sebab itu dikatakan juga bahwa persoalan bahasa sangat kompleks sebagaimana persoalan realitas. Melalui bahasa orang dapat berkomonikasi, namun dengan bahasa pula seseorang bisa salah tafsir.

Karya sastra seringkali dijadikan pengarang sebagai alternatif atau jalan lain ketika semua jalan telah tertutup. Dengan realitas sebagai sumbernya yang kemudian ditarik kedalam ruang imajinasi melalui kontemplasi dan menggunakan bahasa sebagai media penyampaiannya kepada publik (Ratna, 2004; Syakur and Panuju, 2020). Berbicara persoalan sastra dan kehidupan, bahwa sastra itu sendiri sangat erat hubungannya dengan filsafat atau agama (Syakur, 2018b; Syakur and Azis, 2020). Bahkan sampai sekarang sastra masih berperan sebagai medan aktualisasi pemikiran-pemikiran filsafat atau agama. Melihat adanya keterkaitan antara sastra dan filsafat, maka tidak mengherankan jika akhirnya timbul suatu pandangan bahwa sastra sebenarnya mengungkapkan 
masalah kehidupan realita kemake (Ningsih et al., 2014). Maka dari itulah sebagai salah satu genre sastra, karya juga akan memberikan informasi yang berhubungan dengan masalah kehidupan atau dinamika sosial yang dipaparkan pengarang melalui penggambaran yang aktual dan imajinatif. Sehingga dengan sendirinya visi sastrawan bisa berindikasi pada ide pandangan hidupnya yang merupakan tradisi budaya filsafat, agama atau kepercayaan akan kebenaran lainnya yang berbentuk kemanusiaan yang utuh, kemudian dituangkan dalam sebuah karya sastra.

Filsafat eksistensi menarik untuk dikaji karena hal itu berkaitan erat dengan keberadaan mausia dan pemahaman terhadap hakekat manusia yang sebenarnya. Memahami filsafat lewat sastra dirasa lebih mudah decerna daripada memahami filsafat sebagai ilmu murni.

Sedangkan novel "tuhan, ijinkan aku menjadi pelacur!" adalah salah satu novel Muhidin M. Dahlan, yang banyak mengandung unsur eksistensialisme yakni keberadaan manusia, yang merupakan suatu realita atau kenyataan yang dihadapi manusia. Eksistensialisme menunjukkan ciri-ciri yang lincah dalam membahas dan menganalisis eksistensi manusia, yaitu cara berada manusia serta kebebasannya sebagai subyek yang berhadapan dengan obyek. Sehingga eksistensialisme seakan-akan memaksa orang untuk menyadari dengan melihat realitas, bahwa dunia dan eksistensi manusia itu tidaklah tampil dengan mantap, sempurna dan selesai (Syakur, 2018a). Artinya manusia menghadapi berbagai masalah yang eksistensial seperti kecemasan, kemuakan, kebebasan, kematian, dan sebagainya. Kesemuanya itu benar-benar merupakan fakta yang empiris dalam diri manusia. Hal tersebut diatas sangatlah menarik untuk diselidiki dan dianalisis secara serius dan kritis, untuk kemudian diambil saripatinya. Aspek Eksistensi yang dijadikan bahan analisis, mengacu pada nilai-nilai makna dan kultur masyarakat Indonesia yang agamis, pandangan hidup yang luhur, dan hubungan kemanusiaannya yang kuat. Sementara nilai-nilai keagamaan yang dimaksud adalah persoalan hubungan vertikal yang mengejawantah dalam hubungan horisontal. Sedangkan pandangan hidup yang dimaksud adalah nilainilai yang berhubungan dengan atau antar manusia yang bisa mengejawantah menjadi hubungan vertikal. Bagaimanapun hubungan keduanya memiliki keterjalinan yang akut untuk mengungkap sebuah kebenaran.

\section{METODE}

Jenis penelitian ini menggunakan penelitian dengan metode deskriptif kualitatif mangacu pada penelitian yang dilakukan oleh (Hariyati and Syakur, 2018; Syakur and Panuju, 2020), sedangkan dalam pengumpulan data dan sumber data penelitian ini menggunkan metode dokumentasi yang data-datanya bersumber dari data kepustakaan yang sesuai dengan objek penelitian ini baik berkenaan dengan data primer maupun data sekunder.

Analisis data melalui cara eksplorasi data yang digunakan berupa data penelitian yang diperoleh dengan menggunakan buku karya sastra dengan judul "Tuhan, Ijinkan Aku Menjadi Pelacur". Hasil penelitian dilaporkan dalam bentuk statistik deskriptif.

\section{HASIL}

Nilai-Nilai Eksistensialisme: Absurditas Kebebasan Manusia 
Eksistensialisme merupakan suatu pemberontakan terhadap kepribadian dari zaman industri modern atau zaman teknologi, serta pemberontakan terhadap gerakan massa pada zaman sekarang. Masyarakat industri condong untuk menundukkan orang seorang kepada mesin; begitulah gambaran faham eksistensialisme.

\section{Eksistensialisme Sebagai Suatu Reaksi}

Eksistensialisme secara etimologis adalah apa yang ada dan apa yang memiliki aktualitas (ada), menekankan bahwa sesuatu itu ada, berada dalam esensi dengan kodrat inherennya, ia adalah keempurnaan. Atau yang secara terminologi merupakan aliran, suatu gerakan pemberontakan yang dilakukan oleh masyarakat modern dan masyarakat tradisional terhadap beberapa sifat dari filsafat.

\section{Eksistensialisme: Antara Religius dan Non Religius (Atheist)}

"Tuhan tidak ada! Aku ateis!" Kalimat klise yang bombastis ini biasanya merupakan akhir dari ketidakpuasan yang panjang baik terhadap institusi maupun doktrin agama; kulminasi dari renungan eksistensialisme yang menyertainya. Pernyataan tersebut sekaligus juga merupakan awal dari pembantahan sistemik yang mulai diluncurkan sebagai respon terhadap pernyataan tersebut.

\section{PEMBAHASAN}

\section{Nilai-Nilai Eksistensialisme: Absurditas Kebebasan Manusia}

Kegiatan-kegiatan intelektual sangat berkurang seperti sekarang ini, orang sering mudah kehilangan persepektif yang lebih luas. Perkembangan masyarakat misalnya pandangan yang lebih mengutamakan naiknya pendapat nasional daripada pemberantasan kemiskinan dan ketidak adilan sosial serta ketimpangan pada kelas-kelas masyarakat. Namun kebersamaan dalam hidup sedikit banyak masih ada meskipun dengan berkembangnya zaman yang begitu pesat dari setiap waktu, yaitu pola kehidupan modern.

"Belum lagi ada "walimahan", seisi pos akan berpesta dan "walimahan" itu kerap terjadi pada malam minggu. Maka kamipun membeli makanan yang melimpah. Lalu memasaknya beramai-ramai. Menurut mbak Auliah, sejak dulu pos kami ini sering dipakai untuk acara walimahan. Diacara inilah aku mengabkrapkan diri dengan para ikhwan dan bercanda bersama dengannya. Tak jarang mereka melemparkan ledekan padaku. Misalnya, "itu, Mbak Kiran kayaknya mau nikah tuh.” begitu ramainya, begitu mengasikkannya. Makannya banyak disini secara diam-diam aku belajar memasak. Dari para ukhti itu, aku belajar menyusun menu. Lantas belajar menata. Pendeknya, kami kekenyangan dan......

\section{Kesadaran Diri}

Pandangan para eksistensialis, kesadaran diri merupakan kapasitas kemungkinan manusia bisa hidup sebagai pribadi, dalam arti kata yang sesungguhnya. Kesadaran akan semakin tinggi tingkat kesadaran seseorang, maka akan semakin utuh pula pribadi seseorang tersebut (Sindhunata, 1982). mengatakan bahwa "Bukanlah kesadaran manusia yang menentukan keadan mereka melainkan sebaliknya keadaan sosiallah yang menentukan kesadaran mereka", sementara kebebasan manusia bisa terjadi bila kesadaran manusia 
diubah dan diganti. Beramai-ramai mereka menolak hukum negara dan moralitas sebagai suatu khayalan religius, dan berakhir dengan sesuatu harapan bahwa dengan kritik itu semua ketidak beresan dunia akan lenyap dengan sendirinya. Seperti dalam kutipan dibawah ini:

"Salahkah aku mencoba jalan hidup dengan menjadi pelacur? Salahkah aku, bila dengan menjadi pelacur, aku bisa mendapatkan kembali kekuatanku yang sudah diporak-porandakan oleh Tuhan dan kaum lelaki maniak, kaum lelaki munafik. Kurasa-rasai betapa aku sudah berbeda dengan aku yang lalu-lalu. Sekarang aku lebih percaya diri bahwa aku memiliki kekuatan untuk menaklukkan banyak hal, pertama lelaki. Kekuatan yang tak pernah aku duga, sebab dulu ketika bersama lelaki, aku terseret oleh kehendak-kehendak mereka, menangis-nangis cengeng dibawah duli kuasanya".

"Dulu, aku tunduk-tunduk kepadamu, sujud-sujud padamu karena kekerdilanku, karena aku tergantung. Sekarang telah kutemukan kekuatanku dan aku tahu siapa aku. Aku adalah perempuan yang bisa menundukkan banyak sekali kaummu. Lihat saja nanti" (Dahlan, 2007).

Dilihat dari beberapa kutipan diatas denga secara tidak langsung tokoh Nidah Kirani mempunyai gagasan yang kuat terhadap eksistensi sebagai manusia. Gagasan menjadi kuat bukan dalam dirinya sendiri, melainkan karena menjadi (memenuhi atau mengungkapkan) kebutuhan real manusia. Hubungan dan tingkah laku material manusia juga akan menentukan kesadaran dan gagasannya. Kegiatan kesadaran mengalir langsung dari kegiatan material, yakni proses manusia. Tapi dalam hal ideologi (yang meliputi ajaran agama, politik, hukum, moralitas dan agama), kenyataan yang ada itu dicerminkan secara terbalik. Dengan demikian gagasan dan teori fungsinya selalu membela dan membenarkan kepentingan suatu kelas, dan itulah yang disebut ideologi. Dalam praktek, ideologi yang sebenarnya merongrong martabat manusia diterangkan dan dibenarkan atas nama gagasangagasan luhur.

\section{Kebebasan dan Tanggung Jawab}

Dalam masalah ini, Sartre yang mengemukakan kebebasan manusia sebagai tema sentral filsafatnya berpendapat; bahwa kebebasan selalu melibatkan tanggung jawab. Dan ini adalah efek pertama dari eksistensialisme yang berkaitan dengan kebebasan manusia (Muzairi, 2002).

Sementara kebebasan merupakan sebuah konsep yang berkontribusi terhadap aliran eksistensialisme, karena aliran eksistensialis selalu saja menekan kepada kebebasan sebagai ciri esensial dari manusia. Para eksistensialis melihat kebebasan selalu didalam kaitan dengan tanggung jawab (dituntut tanggung jawab) untuk membuat putusan-putusan atau memilih tindakan dalam rangka untuk kehidupan atau keberadaan dirinya. Seperti dalam kutipan dalam novel di bawah ini:

"Karena tak gampang usaha pembebasan cap jalang itu, maka ia menantang bagiku. Tidak ada satupun raut sesal dari semua pilihan itu. Tidak ada. Maka sebagaimana aku tak pernah menyesali segala keputusan yang kubuat, maka aku juga tak boleh menyalahkan jebakan-jebakan pahit hidup yang sudah menapisnapisku. Aku sudah jauh melela dalam riak hidup sebagaimana kosong penuhnya aku malam ini. Sebagaimana malam yang pekat, aku ingin menyempurnakan kegelapanku dan berusaha semampu-mampuku untuk bergiat membongkar lingkungan yang mengitariku karena banyak konsep yang menjerat memenjara. $\mathrm{Ah}$, aku memerlukan keberanian yang melimpah untuk membongkar konsep itu; 
konsep yang kadung sudah sangat wajar dijaga-jagai hukum sosial disekitarku" (Dahlan, 2007).

Ditambah lagi.....

"Dan keinginanku menjadi pelacur adalah salah satu keinginan terjujur yang bisa kuberitahukan kepada-Nya".

Dalam konteks diatas dapat di tarik kesimpulannya bahwa tokoh Nidah Kirani menyatakan bahwa dalam dirinya terdapat kebebasan sebagai wujud dari eksistensinya. Sementara melihat dirinya sudah ada dibelakang pilihannya dan dihantui oleh suatu cita-cita yang menjadi sebab bagi dirinya sendiri, dimana agama-agama menyebutnya Tuhan. Sedangkan menyangkut nilai moral dan agama, adalah bagi yang bertendensi religius, sedang yang tidak, persoalannya akan lain. Permasalahan berlaku, jika seseorang itu bebas dalam memilih dengan suatu kriteria, berarti ia harus membedakan antara keyakinan yang benar dalam memilih, dan juga sebaliknya. Sekaligus (Sartre, 1993) mengatakan bahwa apabila seseorang tidak meraskn kegelisahan, ia pasti menutup-nutupi penderitaannya. Jelaslah bahwa penderitaan yang dimaksudkan disini bukanlah penderitaan yang akan membawa kita pada kesunyian atau keadaan yang tidak melakukan tindakan apapun. Penderitaan ini adalah penderitan yang murni dan sederhana, yaitu jenis penderitan yang telah dikenal baik oleh mereka yang telah dapat bertanggungjawab.

\section{Kesepian dan Keterasingan}

Kesepian dan keterasingan ini menjadi masalah pada masyarakat modern karena manusia yang sepi didalam keramaian dan kebisingan massa yang menandai adanya kekosongan yang kian memuncak sejalan dengan pengalaman keterasingan yang semakin intens sebagia konsekuensi dari sistematisasi dan otomatisasi kerja. Didalam keterasingan, manusia merasa dirinya asing bukan hanya saja terhadap sama dan pekerjaannya, tetapi juga terhadap dirinya sendiri.

Keterasingan atau alienasi adalah suatu gejala dimana manusia merasa terasing dari kehidupan sosialisnya, manusia merasa bukan bagian dari sistem sosial yang sedang berlaku saat ini. Eksistensialisme muncul untuk mengembalikan eksistensi manusia dari berbagai keterasingan berbagai dimensi. Manusia merasa asing disebabkan oleh beberapa faktor bisa bersifat psikologis, sosiologis dan sitem sosial.

Dalam novel Muhidin M. Dahlan ada berbagai macam bentuk keterasingan yang seringkali dialami oleh tokoh Nidah Kirani serta rasa kekecewaanya yang tak henti-henti merangkeng dalam jiwa dan pikirannya, seperti kutipan dibawah ini:

"Maafkan Tuhan bila aku tidak lagi mengharapkan kuasamu. Kalau kau mau dan menyebutku sebagai mahluk ciptaanmu yang tidak tahu diri tidak tahu terimakasih, silahkan.... silahkan...., cabut saja jiwaku. Tapi aku tak akan membiarkan begitu saja kau mencabutnya. Sebab aku akan lawan dan tak mau turut pasrah dalam permainanmu. Kau yang menciptakanku dan hidupku sama sekali tak pernah kuinginkan. Jadi kau yang harus bertanggung jawab atas semuanya. Maafkan Tuhan atas sikapku yang kasar ini. Maafkan (Dahlan, 2007).

Tak terasa sudah hampir empat pekan aku terkurung dalam kamar kos. Dan ragaku sudah serapuh ini. Sudah sekering ini. Rambutku belum juga tesisir 
ketika kupaksakan tubuhku yang telah kehilangan kematangannya untuk melangkah dan berjalan mengitari rumah kos (Dahlan, 2007).

Berangkat dari beberapa pemaparan dan pemahaman tersebut diatas bahwa dengan secara tidak langsung ancaman yang melekat pada kondisi kemanusiaan kita. Ancaman ini membangkitkan "kecemasan eksistensial." Sikap kita terhadap ancaman ini barangkali merupakan aspek terpenting yang menentukan apakah hidup kita bermakna atau hanya berupa kesia-siaan.

Ada beberapa fase dalam hidup yang tidak bisa di tepis atau menolaknya, (Abidin, 2002) yaitu: Kematian: Kita semua adalah mahluk yang tidak abadi. Kematian sewaktu-waktu menjemput kita. Takdir: takdir kita mungking suatu kesengsaraan atau malapetaka, yang tidak dapat diramalkan atau dikendalikan. Pilihan: keharusan untuk membuat pilahan

\section{Kematian}

Para eksistensialisme mengankat kematian sebagai tema filsafat yang penting, sebab keatian menurut mereka, kematian yang tidak bisa dihindarkan da merupakan refleksi dan keterbatasan manusia. Pengangkatan tema kematian ini menjadikan para eksistensialisme banyak dikritik sebagai orang-orang yang mempersoalkan kematian dengan pesimisme tinggi, suatu kritik yang terbukti keliru jika kita membaca tulisan-tulisan para eksistensialis dengan cermat.

Sartre dan Camus memandang kematian sebagai puncak absurditas hidup manusia, menurut mereka dengan kematian, manusia yang berasal ketiadaan mengahiri keberadaannya dan kembali kepada ketiadaan mutlak. Seperti kutipan dibawah ini:

"Ketika absurditas melemparku, maka ranah pelarianku adalah obat-juga tentu saja seks. Dan biasanya aku menenggak 10 atau 15 pil. Dan setelah melakukn itu baru aku terdiam sambil mataku menagkap maya yang nanar (Dahlan, 2007). Ditambahkan "Oh bapak, begitu kompleks sakit yang kau deritai itu. Ginjalmu teserang. Dan kau hampiri oleh ragam penyakit. Bapakku.... bapakku, hanya satu sebetulnya obat terbaik untukmu, maaf, MATI!" (Dahlan, 2007).

Lalu kesadaran dalam berfikir Nidah Kirani lenyap dengan seketika, ketika tertimpa berbagai macam musibah yang ia hadapi terungkap rasa dalam ketakacuhannya terhadap Tuhan, Ayah dan masa depan menjadi buram, dengan hal yang demikian barangkali puncak absurditas atau klimaks dari eksistensi Nidah Kirani akan tetapi dunia tidak sekedar absurd tetapi juga dunia itu irrasional karena tidak mampu menjelaskan tragedi-tragedi yang meimpa manusia. Dan makna atau tujuan hidup manusia. Kematian adalah suatu hal yang irrasional dan tidak dapat dijelaskan. Maut (kematian) adalah sesuatu yang absurd. Hal itu dikarenakan oleh kenyataan bahwa maut tidak bisa ditunggu saat tibanya, sekalipun dapat dipastikan tibanya (Hassan, 2005).

Maut adalah absurd karena tibanya diluar dugaan dan pilihan kita sendiri. Maut tidak mempunyai makna apa-apa bagi eksistensi sebab begitu maut tiba, eksistensipun selesailah. Jika kita memandang kematian sebagai puncak absurditas hidup manusia. Menurut mereka, dengan kematian, manusia yang berasal dari ketiadaan mengakhiri keberadannya dan kembali kepada ketiadaan yang mutlak. Secara tidak langsung Nidah Kirani mengadopsi dari pemikiranpemikiran sartre dan Camus, juga memandang kematian tidak sekedar sebagai kematian fisik melainkan sekaligus merupakan lambang kematian ide manusia 
yang disebut sebagai mati filosofis manusia yang berulang terus menerus sepanjang hidupnya ketika ia tidak mampu memahami segala peristiwa hidup ini.

\section{Eksistensialisme Sebagai Suatu Reaksi}

Ditinjau dari sudut pandang eksistensialisme maka eksistensi manusia adalah suatu proses yang dinamis, suatu "menjadi" atau "mengada". Ini sesuai dengan asal kata eksistensi itu sendiri. Yakni existere yang artinya "ke luar dari" atau "mengatasi" dirinya sendiri. Jadi, eksistensi tidak bersifat kaku dan terhenti, melainkan lentur dan mengalami perkembangan atau sebaliknya kemunduran, tergantung pada kemampuan individu dalam mengaktualisasikan potensipotensinya (Syakur, 2014). Oleh sebab itu, arti istilah eksistensi analog dengan " kata kerja", bukan "kata benda" (Abidin, 2002).

Disini eksistensialisme ingin kembali mengembalikan posisi manusia sebagai subjek yang berkehendak (will of the power kata Nietzsche). Begitulah Sartre kemudian membalik logika (ergo sum Cartesian) itu dengan "Aku Ada, Maka Aku Berfikir".

Perang dunia ke dua dengan kenyataan akibat yang di timbulkannya, telah menggeser perenungan filosofis klasik (rasionalisme yunani dan idealisme hegelian), dengan memunculkan gagasan manusia sebagai center of exellent dari setiap persoalan hidup, bukan mesin dan alam. Seperti dalam cuplika di bawah ini:

"Tuhan, kenapa aku kau perlakukan seperti ini. Kamu tahu betapa aku bersungguh - sungguh berniat untuk menjadi hamba. Lihatkah kau apa yang kulakukan selama ini. Aku telah berinfaq sedemikian banyak. Maka lebih besar dari yang lain-lain di jalan yang kau ridhai. Kalau malam aku dirikan sholat. Itu semua kutujukan untuk mengabdi kepadamu semata. Tapi mengapa itu semua harus berujung dengan kekecewaan" (Dahlan, 2007).

Disini terlihat, adanya bentuk sikap yang dilakukan oleh tokoh Nidak kirani tentang semua pandangan mengenai beberapa segi dari kenyataan manusia dan diperlakukan sebagai kenyataan manusia yang sebenarnya. Dan kemudian timbul sebuah pertanyaan dalam diri manusia itu sendiri terhadap eksistensi itu sendiri serta memandang manusia berpangkal pada keutuhan manusia, dengan demikian kita dapat mengetahui siapa dan apakah manusia itu. Usaha dan percobaan tersebut dalam sejarah pemikiran manusia telah dimulai dari Plato, Sokrates, sampai Thomas van Aquino, dan dalam bentuk yang lain oleh eksistensialisme itu sendiri.

\section{Eksistensialisme: Antara Religius dan Non Religius (Atheist)}

Cara pembuktian Tuhan oleh kaum teis (dalam konteks ini, gereja) yang menurutnya terlalu evasif (dengan selalu menyatakan bahwa pembuktian Tuhan takkan bisa dilakukan menggunakan nadi-nadi sains) dan subjektif (berdasar pada pengalaman spiritual seseorang yang sifatnya personal alih-alih universal). Filsuf ateis lainnya, dalam artian bahwa Tuhan tidak lain hanya merupakan projeksi dari keinginan manusia untuk menjadi sempurna. Ia bukanlah sebuah entitas omni (segala-maha) yang duduk di singgasana sentral eksistensi dan menduduki puncak hierarki kekuasaan eksistensial; namun Ia hanyalah atribusi dari apa yang didamba-dambakan dalam fantasi manusia. Ia menjadi fantastis dan manusialah yang membentuknya, sehingga manusia (lebih spesifik, menurut Descartes, adalah 'akal') merupakan sentral dari segala sesuatu., masalah antara relasi Tuhan- 
manusia yang demikian adalah teralienasinya manusia dari aktualisasi-diri optimal yang mampu ia lakukan. Manusia tidak lagi mampu bergerak sedekat-dekatnya menuju kesempurnaan karena seluruh atribut baik sudah dipindahkan ke entitas lain (Tuhan) dan secara psikologis manusia tidak lagi berinteraksi dengan ambisi menuju kesempurnaan.

Meminjam kacamata seorang eksistensialis-murni, klaim-klaim ini bermasalah. Apa yang dicoba dibuktikan dalam argumen-argumen ini bukanlah perihal tidak-adanya Tuhan, melainkan error of logic yang inheren dalam sifat atau atribut Tuhan menurut beberapa kelompok beragama. Untuk memercayai sebuah entitas kompleks yang membuat segala macam kehidupan di bumi tanpa proses evolusi, mampu melihat segalanya, bahwa sentral ateisme "Tuhan tidak ada" sama sekali tak terbukti, saat apa yang dipermasalahkan malah atribut apa yang Tuhan miliki. Seperti kutipan di bawah ini:

"Lalu bagaimana aku bisa meyakini Tuhan yang menyiksa begini. Yang tidak bisa kupikir, hanya aku yang dipaksa-paksa untuk bersabar, bersabar, dan terus bersabar entah sampai kapan batasnya. Betapa mudahnya seorang manusia disalahkan oleh sesamanya atas nama di atasnya: TUHAN".....

Ditambah lagi

"Lalu apa bedanya aku ber-Tuhan dan tidak kalau begitu. Ah, aku tidak bisa mengerti maunya Tuhan itu apa. Dan Ia mengipas-ngipas kepercayaanku kepadaNya. Dan kurs kepercayaanku kepada-Nya pun bergerak perlahan tapi pasti ke titik nol".

Salah satu sebab posisi ateisme adalah istilah yang ia gunakan untuknya sendiri. Seperti telah dibahas sebelumnya, kata 'ateisme' secara sederhana berarti paham ketanpaTuhanan, sebuah kata yang mengandung elemen eksistensialistis yang kuat. Hasilnya, ia sulit sekali melindungi dirinya dari pertanyaan-pertanyaan eksistensialis yang stasioner (walau tak absurd). seperti kutipan dibawah ini:

"Tuhan, sampai kapan Kau menyiksa bapakku. Sampai kapan Kau menghabioskan seluruh keringat kami. Emang salah dia apa kepada-Mu sampai Kau begitu kejam? Sudahla, aku saja yang menanggung. Kalau Kau mengambil, ambillah dia dengan baik-baik. Tidak seperti ini: tidak hidup tidak mati”.

Pernyaan diatas, tokoh Nidah Kirani beranggapan bahwasanya makna kehidupan yang setiap saat selalu mengalami peritaan dan kesengsaraan yang dialami oleh manusia. Apa artinya kebahagiaan? Apakah hidup layak dijalani? Kalau masih hidup tidak mempunyai makna, apakah hidup masih pantas dijalani? Mengapa orang tidak bunuh diri saja sebagai jalan keluarnya?. Namun ada satu hal yang ditangkap oleh kesadaran Nidah Kirani, yaitu perasaan absurd, ketika terdapat ketidakharmonisan antara harapan, cita-cita dan keyakinan-keyakinan manusia yang luhur dan mulia, dengan kenyataan pahit dan tidak terpenuhinya keinginan manusia di dunia ini akan kebahagiaan, keadilan dan kesejahteraan. Seperti dalam kutipan dibawah ini:

"Oh bapak, begitu kompleks sakit yang kau deritai itu. Ginjalmu teserang. Dan kau hampiri oleh ragam penyakit. Bapakku.... bapakku, hanya satu sebetulnya obat terbaik untukmu, maaf, MATI!"

Dan ditambahkan

Disaat-saat inilah aku merindukan maut agar segera datang merenggutku. Aku sudah memutuskan diri untuk lebih baik mati. Aku sudah tidak sanggup lagi menghadapi hidup yang absurd ini. Mau pulang, pulang kemana. Saudara jauh semua. Bapak-Ibu lagi bergulat dan tarik-menarik dengan maut. Hidupku sendiri 
kedepan bagaimana, aku tak tahu. Seperti jalan hidupku sudah mencapai titik kebuntuannya yang klimaks.

Tanggapan atas situasi absurd dan perasaan absurd ini, tokoh Nidah Kirani memilih dua jalan penyelesaian, yaitu (1) tidak adanya harapan, dan (2). bunuh diri. Sementara bagi Camus, bunuh diri merupakan pelarian dari pikiran yang lemah. Bunuh diri merupakan sebuah bentuk menegaskan bahwa hidup mempunyai nilai mutlak karena semua tidak dapat dicapai pemenuhannya, maka ditolak. disisi lain bahwa harapan terhadap kepercayaan religius akan keselamatan dan janji hidup bahagia kelak juga sudah ditolak oleh Nidah Kirani. Baginya, harapan adalah pelarian. Mungkin baik jika kita bertolak dari kutipan karya Camus di bawah ini. Dalam bagian akhir Mite Sisifus, Camus mengawalinya dengan kalimat berikut:

"Para dewa telah menghukum Sisifus untuk terus-menerus mendorong sebuah batu besar sampai ke puncak sebuah gunung; dari puncak gunung, batu besar itu akan jatuh ke bawah oleh beratnya sendiri. Mereka (para dewa) beranggapan bahwa tidak ada hukuman yang lebih mengerikan daripada pekerjaan yang tak berguna dan tanpa harapan itu" (Camus, 1999).

Dalam cerita tersebut diatas bahwa tokoh Sisifus mau mewakili gambaran sebagai manusia yang bekerja keras karena hukuman dari para dewa. Seolah-olah mewakili manusia dipenjara dalam pabrik, rumah tahanan, sekolah, birokrasi pemerintahan, yang terjebak dalam aktivisme, bekerja keras tanpa berharap akan kepuasan yang ia peroleh dari hasil kerjanya, namun dalam kejernihan pikirannya ia tetap merasa tenang. Dituntut untuk mampu menciptakan bahagia dalam frustrasinya. Keringat dan letihnya adalah harga yang harus dibayar dari perjuangannya. Ia tetap bekerja mengulangi hal yang sama, sambil menatap ketiadaan ganjaran di puncak gunung perjuangan sana. Dan ini terus berulang selama ia hidup, dihukum di dunia.

Diakhir kisah tragis ini, ada ending yang dibayangkan membahagiakan, "Saya tinggalkan Sisifus di kaki gunung! Kita selalu menemukan kembali beban kita. Namun Sisifus mengajarkan kesetiaan lebih tinggi yang menyangkal para dewa dan mengangkat batu-batu besar. Ia juga menilai bahwa semua baik adanya. Perjuangan ke puncak gunung itu sendiri cukup untuk mengisi hati seorang manusia. Kita harus membayangkan Sisifus berbahagia”.

Konsepsi Ketuhanan semacam ini lantas menggiring kita untuk berpikir bahwa Tuhan adalah personal. Tapi kaum Atheis terus mendesak. "Jika Dia benarbenar ada, kenapa Dia begitu angkuh? Kemana Dia ketika terjadi ketidakadilan? Kemana Dia ketika terjadi pembantaian? Mengapa Dia langsung berbalik badan ketika kita sudah diciptakannya?" dan seterusnya. Pertanyaan-pertanyaan tajam semacam itu, mereka dengan tegas mengatakan bahwa Tuhan itu tidak ada. Mereka mengatakan bahwa Tuhan itu hanyalah proyeksi pikiran belaka. Mereka menolak takdir manusia yang dijadikan budak bagi tuan besar itu. Mereka menolak Diktator. Kaum Atheis itu memang tidak bisa dipandang sebelah mata. Mereka adalah ilmuwan-filosof yang mati-matian menentang campur tangan Tuhan. Untuk itu mereka menciptakan berbagai macam ilmu pengetahuan yang benar-benar canggih dan rasional. Satu hal yang pasti, kaum Atheis ini sangat gigih dalam belajar. Mereka begitu serius menuntut ilmu karena mereka adalah kaum Atheis, kaum yang mengandalkan diri sendiri. Namun, ada kekeliruan fatal dalam diri kaum Atheis ini. Para filosofnya sungguh-sungguh keliru ketika menyangka bahwa mereka tengah membawakan pemahaman baru tentang 
peniadaan Tuhan. Sebab, argumen peniadaan Tuhan itu sebenarnya telah diucapkan berabad-abad, Tuhan adalah Ketiadaan yang darinya kita berasal dan kepadanya kita akan kembali.

Maka, absurditas bukanlah seruan untuk mengakhiri hidup dengan bunuh diri. Seruan Nidah Kirani adalah panggilan untuk menjadi jujur dengan diri sendiri, panggilan untuk menjalani hidup secara otentik juga meskipun tidak ada janji-janji akan kebahagiaan hidup nanti dan seruan untuk mengatasi "cuek"-nya dunia dan ketidakpedulian Tuhan atas kenyataan pahit dan penderitaan. Seruan Tokoh Nidah Kirani adalah panggilan untuk bertindak memperbaiki kondisi hidup manusia dengan segala cara. Namun pertama-tama itu dilakukan dengan melawan ketidakpedulian itu sendiri, yang menjadi akar dari ketidakadilan, penderitaan dan absurditas. Pikiran kita bertemu pada bata-batas yang terakhir, suatu kekosongan yang tidak dpat disi lagi oleh filsafat. Kegagalan filsafat pad batas ini memperlihatkan bahwa manusia menantikan suatu jawaban yang tidak dapat diberi oleh pemikiran sendiri. Oleh filsafat, mnusia digambarkan sebgai eksistensi yang menantikan transendensi (Sastrapratedja, 1982). Oleh sebab itu dapat dikatakan, sebagai kritik positif bahwa metafisika memperlihatkan dengan sangat jelas sampai dimana akal budi manusia dapat pergi. Yaitu: hanya sampai kehadiran tersembunyi dari keilahan. Tetapi ruang yang diciptakannya dapat diisi dengan iman sendiri.

\section{KESIMPULAN}

Kebebasan yang terdapat dalam novel Tuhan, ijinkan aku menjadi pelacur adalah absurditas dalam hidup, yang merupakan satu kesatuan dengan persoalan Kebebasan manusia, antara "kebebasan untuk" dan "Kebebasan diri". Sebuah gambaran dalam membicarakan 'ada' sebagai dirinya sendiri, dalam hubungannya dengan 'aku' (dalam pengertian eksistensi). karena dia tidak bisa menghendaki kepastian justru karena kesadarannya. Sehingga menjadikan hidup bagi tokoh Nidah Kirani menjadi absurd, tampa makna, memuakkan, dan menjemukan. Sementara pada persoalan penderitaan, pemberontakan, keterasingan, kesepian dan kematian yang hampir mewarnai semua tulisannya. Kirani memandang hakekat adalah hidup yang dijalaninya adalah rasa kekecewaan, serta pemberontakan dan terus menerus mencari eksitensi dirinya hingga sampai kematian itu tiba. Sementara konsep dari eksistensialisme. "manusia itu adalah bebas,"adi kebebasan manusia adalah ketika manusia menentukan dirinya sendiri dalam mengisi dan menentukan pilihan-pilihan dalam hidupnya.

Eksistensialisme inginkembali mengembalikan posisi manusia sebagai subjek yang berkehendak. Begitulah Sartre kemudian membalik logika ergo sum Cartesian itu dengan "Aku Ada, Maka Aku Berfikir". Munculnya eksistensialisme dalam novel Tuhan, Ijinkan Aku Menjadi Pelacur!.karya Muhidin M dahlan dilatar belakangi oleh kehidupan pribadi yang dilalui oleh Tokoh Nidah Kirani. Ada tragedi yang besar seorang sastrawan yang sangat memperhatikan dari berbagai persoalan yang menimpa tokoh Nidah Kirani, yaitu kegagalan untuk menjadi islam yang kaffah yang menjadi harapan dalam hidupnya, berpindah haluan atau aliran dikarenakan banyak persoalan yang ia hadapi sehingga menjadi pemberontak terhadap ajaran-ajaran agama. Maka implikasi dari tragedi tersebut merupakan sebuah refleksi pemikiran serta pengalamannya mengenai dari 
berbagai persoalan hidup. Bahwa tragedi-tragedi yang menimpa manusia, keterasingan dari lingkungan sekitarnya atau diri sendiri, kesedihan yang menimpa manusia serta hal-hal yang membuat manusia terpojok, terasing itu semua harus dijadikan titik tolak kesadaran manusia akan hakikat dan jati diri manusia.

\section{SARAN}

Tokoh Nidah Kirani yang dikisahkan dalam novel Tuhan, ijinkan aku menjadi pelacur, adalah gambaran sosok manusia yang lemah imannya. Ia harus menemukan orang yang secara tepat dapat menjawab segala pertanyaannya tentang Tuhan, tentang Iman, tentang Cinta. Para pembaca yang mengganggap novel ini menyesatkan, mungkin mereka berpikir bahwa novel ini menjelekjelekkan para aktifis Islam. Tapi bagiku, ini bukan sebuah ejekan, tapi sebuah kenyataan, bahwa tak ada manusia yang sempurna. Bahwa seorang agamis sekalipun dapat terjerumus dalam dunia hitam. Bahwa hitam-putih dunia ini adalah relatif, tidak pernah mutlak. Manusia dapat berubah menjadi baik dan juga dapat berubah menjadi buruk dengan tidak mengenal waktu kapan saja dan dimana saja. Semua sudah diatur oleh-Nya. Mungkin saja seorang pelacur masuk surga. Itu hak prerogatif Tuhan! Maka jangan pernah pula merendahkan orang lain, apapun dan siapapun dia! Tuhan tahu segala yang tak diketahui manusia.

\section{DAFTAR RUJUKAN}

Abidin, Z. (2002). Analisis Eksistensial untuk Psikologi dan Psikiatri. Bandung: Refika Aditama.

Camus, A. (1999). Mite Sisifus: Pergulatan dengan Absurditas. Jakarta: Gramedia Pustaka Utama.

Dahlan, M. M. (2007). Tuhan, Izinkan Aku Menjadi Pelacur. Memoar Luka Seorang Muslimah. Yogyakarta: ScriPtaMenent.

Hariyati, N. R., and Syakur, A. (2018). Penerapan Strategi Membaca Kritis di Akademi Farmasi Surabaya untuk Menunjang Kecakapan Literasi Menuju Era Revolusi Industri 4.0. In "Prosiding Seminar Nasional \& Internasional", Vol. 1.

Hassan, F. (2005). Berkenalan dengan Eksistensialisme. Jakarta: Dunia Pustaka Jaya.

Muzairi, H. (2002). Eksistensialisme Jean Paul Sartre Sumur Tanpa Dasar Kebebasan Manusia. Yogyakarta: Pustaka Pelajar.

Ningsih, A., Sabat, Y., and Syakur, A. (2014). Comic Strips as Media to Develop Student's Writing Ability in Composing Recount Text for The Tenth Graders of SMA Muhammadiyah 2 Sidoarjo (Komik Strips Sebagai Media Untuk Mengembangakan Kemampuan Menulis Siswa Dalam Mengarang Teks Recount. English Education 2.

Poespoprodjo, W. (1999). Filsafat Moral: Kesusilaan dalam Teori dan Praktek. Bandung: Pustaka Grafika.

Rasjidi, H. M. (1984). Persoalan-Persoalan Filsafat. Cet. I. Jakarta: Bulan Bintang

Ratna, N. K. (2004). Teori, Metode \& Teknik Penelitan Sastra: dari Strukturalisme Hingga Postrukturalisme: perspektif wacana naratif. Yogyakarta: Pustaka Pelajar. 
Sartre, J. P. (1993). Eksistensialisme er humanisme. Cappelen.

Sastrapratedja, M. (1982). Manusia Multi Dimensional: Sebuah Renungan Filsafat. Jakarta: PT. Gramedia.

Sindhunata. (1982). Dilema Usaha Manusia Rasional: Kritik Masyarakat Modern oleh Max Horkheimer dalam Rangka Sekolah Frankfurt. Jakarta: PT Gramedia

Suparlan, S. (2005). Dasar-dasar Filsafat. Yogyakarta: Ar-Ruzz Media.

Syakur, A. (2014). Analisis Dialek Lokal Sebagai Penanda Identitas Lokal Individu (Studiinterlanguage Mahasiswa Di Ilmu Administrasi Negara Stisospol "Waskita Dharma" Malang). JAMAK 1, 14-18.

Syakur, A. (2018a). Hubungan Kualitas Pelayanan Terhadap Kepuasan Mahasiswa dan Loyalitas Mahasiswa Ditinjau dari Model Pembelajaran di Akademi Farmasi Surabaya. Reformasi: Jurnal Ilmiah Ilmu Sosial dan Ilmu Politik 8, 100-108.

Syakur, A. (2018b). Using Cooperative Learning Strategies to Improve the Student's Reading Comprehension. Jurnal Edukasi 4.

Syakur, A., and Azis, R. (2020). Developing Reading Learning Model to Increase Reading Skill for Animal Husbandry Students in Higher Education. Britain International of Linguistics Arts and Education (BIoLAE) Journal 2, 484-493.

Syakur, A., and Panuju, R. (2020). Peran Strategis Public Relation dalam Pengembangan Reputasi Pendidikan Tinggi: Studi Kasus Promosi di Akademi Farmasi Surabaya. Briliant: Jurnal Riset dan Konseptual 5, 128136. 